\title{
Letter to Editor Regarding the OCEAN Study [Letter]
}

\author{
Barbara P Yawn' \\ Barry Make ${ }^{2}$ \\ David Mannino 3 \\ Fernando J Martinez $\mathbb{D}^{4}$ \\ Meilan $\mathrm{K} \mathrm{Han}^{5}$ \\ 'Department of Family and Community \\ Health, University of Minnesota, \\ Minneapolis, MN, USA; ${ }^{2}$ Pulmonary \\ Sciences and Critical Care Medicine, \\ National Jewish Health, Denver, CO, \\ USA; ${ }^{3}$ College of Public Health, \\ Department of Preventive Medicine and \\ Environmental Health, University of \\ Kentucky, Lexington, KY, USA; ${ }^{4}$ Division \\ of Pulmonary and Critical Care Medicine, \\ Weill Cornell Medicine, New York- \\ Presbyterian Hospital, New York, NY, \\ USA; ${ }^{5}$ Department of Internal Medicine, \\ University of Michigan Health System, \\ Ann Arbor, MI, USA
}

\section{Dear editor}

We read with interest the article by Tamaki et al who in the OCEAN study compared the performance characteristics of the CAPTURE COPD screening tool with the COPD-Q screening tool. ${ }^{1}$ While there is currently an important focus on better understanding the broader scope of symptomatic chronic lung disease, it is useful to remember that the CAPTURE was designed specifically to be used as a screening tool (meaning to be used among those without a COPD diagnosis) for the identification of individuals with clinically significant COPD.

We designed the CAPTURE tool to specifically identify individuals who would benefit from immediate pharmacologic therapy, beyond the preventive strategies that should already be important for everyone in a primary care practice - smoking cessation, up to date immunizations, weight management and regular activity. We defined clinically significant COPD as chronic lung disease meeting the obstructive lung disease lung function definition (FEV1/FVC $<0.70)$ in addition to either FEV1 $<60 \%$ of predicted or evidence of exacerbation like events in the prior year. ${ }^{2}$ These are individuals for whom data have shown immediate benefit with pharmacotherapy in improving quality of life and preventing future exacerbations. ${ }^{3}$ In addition, when CAPTURE was previously validated in a combined primary care and specialty patient study using the 5 questions that OCEAN used with the addition of peak flow assessment, it was found to significantly improve screening outcomes, particularly supporting specificity which has been a concern with many prior screening tools. ${ }^{2}$

The OCEAN study is a valuable reminder that we may need to develop tools for screening for PRISm (Preserved Ratio Impaired Spirometry). ${ }^{4}$ We will learn more about the utility of CAPTURE to detect clinically significant COPD through a large primary care validation and impact study currently being conducted in the US. ${ }^{5}$

\section{Acknowledgments}

The CAPTURE Investigators: Meldrum C, Murray S, Spino C, Leidy N, Tapp H, Dolor R, Joo M, Knox L, Zittleman L, Elder N, Thomashow BM.

\section{Disclosure}

Dr Barry Make reports grants, personal fees from Astra Zeneca, personal fees from Spiration, grants, personal fees from Glaxo Smith Kline, personal fees from Mt. Sinai, personal fees from Web MD, personal fees from National Jewish Health, personal fees from Novartis, personal fees from American
Correspondence: Barbara P Yawn

Email byawn47@gmail.com 
College of Chest Physicians, personal fees from Projects in Knowledge, personal fees from Medscape, personal fees from Verona, personal fees from Boehringer Ingelheim, personal fees from Mylan, personal fees from Third Pole, personal fees from Phillips, personal fees from Eastern Pulmonary Society, grants from NHLBI, personal fees from Wolters Kluwer Health, personal fees from Optimum Patient Care Global Limited, personal fees from Integritas Communications, personal fees from Quintiles, outside the submitted work. Dr David Mannino reports personal fees from GlaxoSmithKline, outside the submitted work. Dr Fernando Martinez reports grants, personal fees, non-financial support from AstraZeneca, personal fees from Boehringer Ingelheim, grants, COPD Study Steering committee from Chiesi, personal fees from CsL Behring, non-financial support, COPD Ad Board from Gala, grants, non-financial support, COPD Ad Boards, Study Steering Committee, Non-branded presentations; AZ is an independent sponsor of the NHLBI CAPTURE validation study from GlaxoSmithKline, COPD Study adjudication committee from Medtronic, personal fees from Novartis, personal fees from Polarean, COPD Advisory Board from Pulmonx, grants, personal fees from Sanofi/ Regeneron, personal fees from Sunovion, personal fees from Teva, personal fees from Theravance/ Viatris, COPD Advisory Board from Verona, during the conduct of the study. Dr Meilan K Han reports personal fees from AZ, personal fees from BI, personal fees from Chiesi, personal fees from Cipla, personal fees from GSK, personal fees from Merck, drug supply for clinical trial and clinical trial with funds paid to institution from Novartis, grants from Sunovion, personal fees, consulting and clinical trial with funds paid to institution from Sanofi, personal fees from Teva, personal fees from Verona, outside the submitted work. The authors report no other conflicts of interest in this communication.

\section{References}

1. Tamaki K, Sakihara E, Miyata H, et al. Utility of self-administered questionnaires for identifying individuals at risk of COPD in Japan: the OCEAN (Okinawa COPD casE finding AssessmeNt) Study. Int J Chron Obstruct Pulmon Dis. 2021;16:1771-1782. doi:10.2147/ COPD.S302259

2. Martinez FJ, Mannino D, Leidy NK, et al. A new approach for identifying patients with undiagnosed chronic obstructive pulmonary disease. Am J Respir Crit Care Med. 2017;195(6):748-756. doi:10.1164/rccm.201603-0622OC

3. Decramer M, Miravitlles M, Price D, et al. New horizons in early stage COPD-improving knowledge, detection and treatment. Respir Med. 2011;105(11):1576-1587. doi:10.1016/j.rmed.2010.12.015

4. Wan ES, Fortis S, Regan EA, et al; COPDGene Investigators. Longitudinal phenotypes and mortality in preserved ratio impaired spirometry in the COPDGene Study. Am J Respir Crit Care Med. 2018;198(11):1397-1405. doi:10.1164/rccm.201804-0663OC

5. Yawn BP, Han M, Make BM, et al. Protocol summary of the COPD assessment in primary care to identify undiagnosed respiratory disease and exacerbation risk (CAPTURE) validation in Primary Care Study. Chronic Obstr Pulm Dis. 2021;8(1):60-75.

\begin{abstract}
Dove Medical Press encourages responsible, free and frank academic debate. The content of the International Journal of Chronic Obstructive Pulmonary Disease 'letters to the editor' section does not necessarily represent the views of Dove Medical Press, its officers, agents, employees, related entities or the International Journal of Chronic Obstructive Pulmonary Disease editors. While all reasonable steps have been taken to confirm the content of each letter, Dove Medical Press accepts no liability in respect of the content of any letter, nor is it responsible for the content and accuracy of any letter to the editor.
\end{abstract}

International Journal of Chronic Obstructive Pulmonary Disease

Dovepress

\section{Publish your work in this journal}

The International Journal of COPD is an international, peer-reviewed journal of therapeutics and pharmacology focusing on concise rapid reporting of clinical studies and reviews in COPD. Special focus is given to the pathophysiological processes underlying the disease, intervention programs, patient focused education, and self management protocols. This journal is indexed on PubMed Central, MedLine and CAS. The manuscript management system is completely online and includes a very quick and fair peer-review system, which is all easy to use. Visit http://www.dovepress.com/testimonials.php to read real quotes from published authors. 